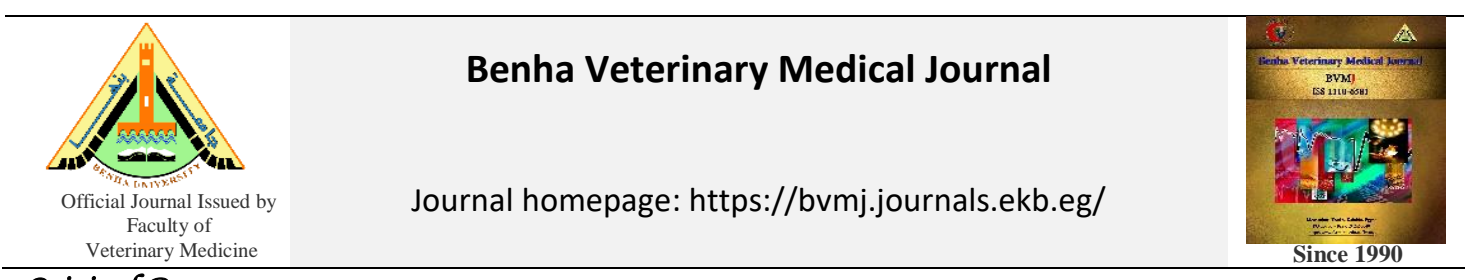

Original Paper

\title{
Improvement quality of minced meat using some essential oils
}

\author{
Amani M. Salem', Nahla A. Abo El-Roos², Mona M. Abd EL-Fatah² \\ ${ }^{I}$ Food Control Department, (Meat Hygiene), Fac. Vet. Med. Benha University, Egypt \\ ${ }^{2}$ Animal Health Research Institute, Shebine EL-Koom Branch, Egypt
}

\section{ARTICLE INFO}

\begin{tabular}{l}
\hline Keywords \\
Antimicrobial effect \\
E. coli \\
Minced meat \\
Natural oils \\
Received $06 / 11 / 2019$ \\
Accepted $01 / 12 / 2019$ \\
Availa6le On-Line \\
/05/122020
\end{tabular}

\begin{abstract}
A total of $5250 \mathrm{~g}$ fresh minced beef were divided into equal groups ( $250 \mathrm{~g}$ of each). E.coli was inoculated into all groups with infective dose $5.36 \pm 0.01 \mathrm{log} \mathrm{cfu} / \mathrm{g}$ except control ones. All samples were treated with thyme oil $(0.5 \%, 1 \%$ and $1.5 \%)$ and garlic oil $(0.5 \%, 1 \%$ and $1.5 \%)$ and examined every $48 \mathrm{hrs}$ at $4{ }^{\circ} \mathrm{C}$ of storage temperature. Sensory examination (overall acceptability) and E.coli count were conducted. Thyme oil(1\% and $1.5 \%)$ and garlic oil $(1.5 \%)$ treated minced beef showed overall acceptability till $8^{\text {th }}$ day of storage. In comparison, thyme oil $(0.5 \%)$ and garlic oil $(0.5 \%$ and $1 \%)$ showed overall acceptability till $6^{\text {th }}$ day. Furthermore, thyme oil $(0.5 \%, 1 \%$ and $1.5 \%)$ decreased count of E.coli $(\log \mathrm{cfu} / \mathrm{g})$ from $5.36 \pm 0.01$ (initial load) to $4.38 \pm 0.02,3.81 \pm 0.2$ and $3.51 \pm 0.14$ with reduction percentages $18.28 \%, 28.92 \%$ and $34.51 \%$ on $6^{\text {th }}, 8^{\text {th }}$ and $8^{\text {th }}$ of storage, respectively. Garlic $(0.5 \%, 1 \%$ and $1.5 \%)$ decreased count of E.coli $(\log \mathrm{cfu} / \mathrm{g})$ to $4.54 \pm 0.2,4.41 \pm 0.3$ and $3.81 \pm 0.1$ with reduction percentages $15.30 \%, 17.72 \%$ and $28.92 \%$ on $6^{\text {th }}, 6^{\text {th }}$ and $8^{\text {th }}$ of storage, respectively. Generally, thyme oil $(1.5 \%)$ proved to be more efficient than other treatments in reduction of E.coli growth in minced beef, therefore, it is recommended to improve safety and extend shelf life of the meat products.
\end{abstract}

\section{INTRODUCTION}

Street-vended foods (SVFs) are ready-made instant meals. Meat has high nutritive composition, so it is being the first choice for animal protein by many people all over the world. Meat and meat products are susceptible to microbial and biochemical deterioration, especially during storage, due to their complex composition of saturated and unsaturated lipids, carbohydrates, proteins, vitamins, and pigments (Lombardi-Boccia et al.,2005 ; Lorenzo etal.,2014 ).After slaughtering of animal, the meat is fabricated into wholesale or retail cuts. Trim and other cuts of meat are undergoing further processing and grounding. This increases surface area of the meat leading to adherence and growth of bacteria (Skandamis \& Nychas, 2001 and Donsì et al.,2011). The most important bacterial pathogens in meat and meat products those are responsible for food-borne infections including $E$. coli (AbdaslamAzza, 2014; Saif-Marwa, 2015).

Pathogenic strains of $E$. coli were divided into (INPEC) causing diarrhea and (EXPEC) including urinary tract infection (UTI), meningitis and septicemia depending on their virulence factors and clinical symptoms (Kaper et al., 2004; Eid and Erfan, 2013).

Essential oils are extracted from several aromatic plants (Saljoughian et al., 2018). They have antioxidant and antibacterial activities that increased their application in the food, cosmetic and pharmaceutical industries (Bakhtiary et al., 2018) and their classification as Generally Recognize as
Safe(GRAS).Therefore, they are used as natural food safer additives in food products (Eset al., 2017).

Recently, using of essential oils became the main substitutes for synthetic additives (Vinceković et al., 2017). However, the use of essential oils has an important drawback as most of them have a strong odour, so it is very important to determine the concentration of essential oil that can be used without modifying organoleptic characteristics of the meat (Shen and Kamdem, 2015).

The essential oil of Thymus vulgaris contains various levels of thymol and/or carvacrol, phenolic derivatives with strong and widespectrum antimicrobial activity (Nevas, 2004 )

The antimicrobial effects of garlic have been attributed to the action of thiosulfinates. Inhibition of certain thiolcontaining enzymes in the microorganisms by the rapid reaction of thiosulfinates with thiol groups was assumed to be the main mechanism. Also, Allicin inhibited other bacterial enzymes such as acetate kinase and phosphotransacetyl -CoA synthetase. Further, it inhibited the DNA and protein synthesis, the effect on RNA is suggesting that RNA could be a primary target of allicin (Focke et al.,1990 and Al-Snafi, 2013).

During the last decade, the antimicrobial activity of garlic and garlic derived organosulfur compounds was widely investigated against both food spoilage bacteria and food borne pathogens (Leuschner and Ielsch, 2003).

* Corresponding author: Mona M. Abd EL-Fatah Animal Health Research Institute, Shebine EL-Koom Branch, Egypt 
The purpose of the current research was to study the antimicrobial effect and acceptability of certain essential oils on reduction of $E$. coli in minced beef.

\section{MATERIAL AND METHODS}

\subsection{Bacterial strain}

Escherichia coli strain $\left(\mathrm{O}_{126}\right) 10^{4} \mathrm{cfu} / \mathrm{g}$ (Barbosa et al., 2009) was obtainedfrom Media Unite, Food Hygiene Department, Animal Health Research Institute, Dokki, Giza, Egypt.

\subsection{Natural oils:}

The ready-made pure herbal oils of thyme $(0.5 \%, 1 \%$ \& $1.5 \%)$ and garlic $(0.5 \%, 1 \% \& 1.5 \%)$ used in this study were purchased from El Captain Company (CAP PHARM). All the used chemicals were of analytical reagent grade. These oils were stored in amber colored bottles at $4{ }^{\circ} \mathrm{C}$ until use.

\subsection{Collection of samples}

A grand total of $5250 \mathrm{~g}$ of the fresh minced beef used in this study was purchased from butcher shops in El Menofiya Governorate. To eliminate natural microbial populations, the purchased meat was sterilized with ultraviolet light at wavelengths $385 \mathrm{~nm}$ for 30 minutes (Morsy et al., 2014).

\subsection{Experimental application:}

Accurately, 5250g fresh minced beef samples were divided into untreated and treated equal groups $(250 \mathrm{~g}$ each) and inoculated with E.coli(5.36 $\pm 0.1 \mathrm{log}$ cfu/g)(initial load) and then mixed with certain concentrations of tested natural oils according to following order:

Control +ve inoculated with E.coli only. Phosphate buffer saline was used for treatment of control (untreated) samples.

A: Treated with thyme oil $0.5 \%$. B: Treated with thyme oil 1\%. C: Treated with thyme oil $1.5 \%$. D: Treated with garlic oil $0.5 \%$. E: Treated with garlic oil $1 \%$. F: Treated with garlic oil $1.5 \%$

The inoculated samples were stored at $4^{\circ} \mathrm{C}$ in refrigerator and examined every 48 hours during storage until spoilage of samples. The experiment was conducted in triplicate according to Kantachote and Charernjiratrakul (2008).

2.4. Sensory examination (overall acceptability) was applied according to Hemin (2013).

2.5. Preparation of sample was done according to ISO (1999).

2.6. E. coli count was performed according to FAD (2001).

\subsection{Statistical analysis:}

The obtained results were statistically evaluated by application of analysis of variance (ANOVA) test according to Feldman et al. (2003).

\section{RESULTS}

Results in table (1) illustrated the effects of various concentrations of thyme and garlic oils on overall acceptability of artificially inoculated minced beef samples with E.coli.
Thyme oil(1\% \& $1.5 \%)$ and garlic oil (1.5\%) showed overall acceptability extended to $8^{\text {th }}$ day of storage. In contrast, thyme oil $(0.5 \%)$ and garlic oil $(0.5 \%$ and $1 \%)$ showed overall acceptability till $6^{\text {th }}$ day of storage. while, control group showed overall acceptability till $4^{\text {th }}$ day.

Table (2) and Table (3) illustrated the antimicrobial effects and reduction $\%$ of various concentrations of thyme and garlic oils on counts of E.coli artificially inoculated into minced beef.

Thyme oil $(0.5 \%, 1 \% \& 1.5 \%)$ decreased count of E.coli ( $\log \mathrm{cfu} / \mathrm{g}$ ) from5.36 \pm .01 (initial load) to $4.38 \pm .02,3.81 \pm 0.2$ and $3.51 \pm 0.14$ with reduction of $18.28 \%, 28.92 \%$ and $34.51 \%$ on $6^{\text {th }}, 8^{\text {th }}$ and $8^{\text {th }}$ of storage, respectively. Garlic oil $(0.5 \%, 1 \% \& 1.5 \%)$ decreased count of E.coli $(\log \mathrm{cfu} / \mathrm{g})$ to $4.54 \pm 0.2,4.41 \pm 0.3$ and $3.81 \pm 0.1$ with reduction of $15.30 \%, 17.72 \%$ and $28.92 \%$ on $6^{\text {th }}, 6^{\text {th }}$ and $8^{\text {th }}$ of storage, respectively. In control group E. coli count increased from5.36 $\pm .01 \log$ cfu/g (initial load) to $6.16 \pm 0.1 \mathrm{on} 4^{\text {th }}$ day. On regard table (2), the differences between the effects of various concentrations of thyme and garlic oils on counts of E.coli $(\log \mathrm{cfu} / \mathrm{g})$ artificially inoculated into minced meat samples were significant $(\mathrm{P} \leq 0.05)$.

Table 1 Sensory evaluation of the control(untreated) and treated samples of minced beef during cold storage at $4^{\circ} \mathrm{C}$.

\begin{tabular}{lcccccc}
\multicolumn{6}{l}{ minced beef during cold storage at $4^{\circ} \mathrm{C}$. } \\
\hline Group & zero day & 2nd day & 4th day & 6th day & 8th day & 10th day \\
\hline Control & 5 & 4 & 3 & 2 & 1 & 1 \\
Thyme $0.5 \%$ & 5 & 4 & 4 & 3 & 2 & 1 \\
Thyme 1\% & 5 & 4 & 4 & 3 & 3 & 2 \\
Thyme 1.5\% & 5 & 5 & 4 & 4 & 3 & 2 \\
Garlic 0.5 & 5 & 4 & 3 & 3 & 2 & 1 \\
Garlic 1\% & 5 & 4 & 4 & 3 & 2 & 1 \\
Garlic 1.5\% & 5 & 4 & 4 & 3 & 3 & 2 \\
\hline
\end{tabular}

(5) Very acceptable, (4) Acceptable, (3) Middle, (2) Unacceptable, (1) Rejected (Hemin, 2013).

Table 2 Mean values of $E$. coli count (log cfu/g) of the examined control(untreated) and treated samples of minced beef during cold storage at $4^{\circ} \mathrm{C}$

\begin{tabular}{llllll}
\hline Groups & zero day & 2nd day & 4th day & 6th day & 8thday \\
\hline Control & $5.36 \pm 0.1^{\mathrm{a}}$ & $5.65 \pm 0.3^{\mathrm{b}}$ & $6.16 \pm 0.1^{\mathrm{d}}$ & Spoiled & spoiled \\
Thyme 0.5\% & $5.36 \pm 0.1^{\mathrm{a}}$ & $5.24 \pm 0.2^{\mathrm{ab}}$ & $4.62 \pm 0.1^{\mathrm{dc}}$ & $4.38 \pm .02^{\mathrm{fc}}$ & spoiled \\
Thyme 1\% & $5.36 \pm 0.1^{\mathrm{a}}$ & $5.16 \pm 0.1^{\mathrm{c}}$ & $4.52 \pm 0.1^{\mathrm{c}}$ & $4.24 \pm 0.2^{\mathrm{fd}}$ & $3.81 \pm 0.2^{\mathrm{fc}}$ \\
Thyme $1.5 \%$ & $5.36 \pm 0.1^{\mathrm{a}}$ & $5.12 \pm 0.1^{\mathrm{c}}$ & $4.42 \pm 0.1^{\mathrm{c}}$ & $4.12 \pm 0.15^{\mathrm{fd}}$ & $3.51 \pm 0.14^{\mathrm{fe}}$ \\
Garlic 0.5\% & $5.36 \pm 0.1^{\mathrm{a}}$ & $5.25 \pm 0.2^{\mathrm{ab}}$ & $4.76 \pm 0.2^{\mathrm{dc}}$ & $4.54 \pm 0.2^{\mathrm{fc}}$ & spoiled \\
Garlic 1\% & $5.36 \pm 0.1^{\mathrm{a}}$ & $5.24 \pm 0.1^{\mathrm{c}}$ & $4.61 \pm 0.1^{\mathrm{dc}}$ & $4.41 \pm 0.3^{\mathrm{fc}}$ & spoiled \\
Garlic $1.5 \%$ & $5.36 \pm .01^{\mathrm{a}}$ & $5.19 \pm 0.2^{\mathrm{c}}$ & $4.48 \pm 0.1^{\mathrm{c}}$ & $4.32 \pm 0.2^{\mathrm{fd}}$ & $3.81 \pm 0.1^{\mathrm{fe}}$ \\
\hline
\end{tabular}

Initial load of $E$.coli at zero hour $=5.36 \pm .01^{a} \log \mathrm{CFU} / \mathrm{g}$. The values represent Mean \pm SD of three experiments. Means within a column followed by different letter ar significantly different $(\mathrm{P} \leq 0.05)$

Table 3 Reduction \% of E. coli count $(\log \mathrm{cfu} / \mathrm{g})$ artificially inoculated into minced beef samples treated with different concentrations of thyme and garlic oils.

\begin{tabular}{llllll}
\hline Groups & Concentration & $2^{\text {nd }}$ day & $4^{\text {nd }}$ day & $6^{\text {th }}$ day & $8^{\text {th }}$ day \\
\hline Thyme oil & $0.5 \%$ & 2.24 & 13.80 & 18.28 & spoiled \\
& $1 \%$ & 3.73 & 15.67 & 20.89 & 28.92 \\
& $1.5 \%$ & 4.43 & 17.54 & 23.13 & 34.51 \\
Garlic oil & $0.5 \%$ & 2.05 & 11.20 & 15.30 & spoiled \\
& $1 \%$ & 2.24 & 13.99 & 17.72 & spoiled \\
& $1.5 \%$ & 3.17 & 16.42 & 19.40 & 28.92 \\
\hline
\end{tabular}




\section{DISCUSSION}

The meat preservatives prevent microbial activity that responsible for deterioration and spoilage of meat and meat products (Yadav and Singh, 2004), but their carcinogenic nature is the major problem for their application. So, natural compounds derived from herbs or plants are suggested to be used either completely or partially substituting chemical preservatives (Gammariello et al., 2008; Hyldgaard et al., 2012).

Natural products and naturally derived compounds from plants may have applications in controlling pathogens in foods (Davidson, 1997; Bowles and Juneja, 1998).

Garlic oil is rich in organosulfur compounds and their precursors "allicin, dially sulfide \& diallyltrisulfides" (Ankri and Mirelman, 1999) inhibiting the growth of a lot of pathogens as E. coli and $S$. aureus by reacting with their cystine, inactivating the thio-containing enzymes or affecting the metabolism of lipids (Song et al., 2004).

Sensory evaluation is an easy, quick and efficient method and used to evaluate the degree of meat freshness depend on organoleptic characteristics such as color, odor, texture and overall acceptability of the product (Haq et al., 2013).

There was a decline of acceptability began after the first day of storage with marked reduction of odor, color, texture and overall acceptability values in the control samples at the $4^{\text {th }}$ day except thyme oil (1.5\%) samples the decrease of acceptability began after the $2^{\text {nd }}$ day (Table 1 ).

Furthermore, the obtained results indicated that the best acceptability quality was attained at thyme oil $(1.5 \%)$ treated minced beef samples then in garlic oil(1.5\%) treated samples, while slight improvement in acceptability of garlic oil $(0.5 \%)$ minced beef samples as compared control samples.

These results agreed with those obtained by Sasse et al. (2009) who reported that many herbs and spices as thyme contain antioxidant components that improve both color and flavor stability in meat. Also, Salem-Amany et al. (2010) indicated that sensory properties of minced beef samples during cold storage $\left(4^{\circ} \mathrm{C}\right)$ were enhanced by treatment minced beef by different concentrations of thyme and garlic oils $(0.5 \%, 1 \%, 1.5 \%)$ compared to the untreated (control) samples and samples contain 1.5\% thyme and garlic oils revealed best enhancement of sensory properties than samples contain $0.5 \%$ of the same oil, and those obtained by Shaltout et al., (2017) whose results were that meat samples containing $2 \%$ thyme oil demonstrated the highest enhancement of sensory attributes, while the samples treated with $1 \%$ of thyme oil demonstrated lower enhancement.

These results are disagreed with those obtained by Solomakos et al. (2008) and Giatrakou et al. (2010) who found the effect of Thymus vulgaris EO on meat was acceptable concerning odor and taste in the range of 0.2 to $0.6 \%$ but unacceptable at $0.9 \%$ on minced beef (Solomakos et al., 2008). Also, Agnieszka et al. (2012) recorded 9 out of 10 persons rejected the meat stored in modified atmosphere with thyme oil due to unacceptable odor, and 6 due to bad taste.

The results in Table (2)showed that the control samples had the highest counts of $E$. coli at any time of cold storage compared to other treatments. Thyme essential oil showed maximum antibacterial activity followed by garlic oil. The inhibition of $E$. coli is related to the concentration of the studied essential oils, since they declined and even inhibited completely, when increasing the concentration of the studied essential oils. As the thyme oil $(1.5 \%)$ has the best antimicrobial activity against $E$. coli than that obtained by $(0.5 \%$ and $1 \%)$. Furthermore, the high concentration of garlic oil $(1.5 \%)$ has a higher inhibitory effect than that obtained by lower concentration $(0.5 \%$ and $1 \%)$.

The major active compound of thyme is thymol, which exerted its antimicrobial action through binding to membrane proteins by hydrophobic bonding and hydrogen bonding, and then changing the permeability of the membranes (Burt, 2004).

These finding were nearly similar with those obtained by Abd EL Fatah- Hend (2016) who found that thyme oil $(1.5 \%)$ had the best antimicrobial activity against E.coli than that obtained by $(0.5 \%$ and $1 \%)$ and the high concentration of garlic oil $(1.5 \%)$ has a higher inhibitory effect than that obtained by lower concentration $(0.5 \%$ and $1 \%$ ).

The low effectiveness of garlic oil in comparison with thyme oil could be attributed to the losses of volatile sulfur compounds, which have high biological activity, during distillation, and also due to the nature of garlic oil itself, which is volatile and hydrophobic (Pranoto et al., 2005). Finally, the present study allowed to conclude that thyme oil $(1.5 \%)$ proved to be more efficient in suppression of E.coli growth in minced meat. So, the use of thyme oil $(1.5 \%)$, as it is safe antimicrobial agent against E.coli, is therefore recommended to improve safety of meat products.

\section{REFERENCES}

1. Abd El-Fattah-Hend, A. (2016):Control of some pathogenic microorganisms in minced meat using essential oils. Ph.D. Thesis, Meat Hygiene, Fac. Vet. Med., Benha Univ.

2. Abd El- Salam-Azza, S. (2014): Molecular detection of antimicrobial resistance for some foodborne pathogens. Ph.D. Thesis (Bacteriology, Mycology and Immunology) Fac. Vet. Med, Zagazig Univ.

3. Agnieszka Nowak, DanutaKalemba, Lucjankrala, Malgorzata Piotrowska, Agata Czyzowska (2012): The effects of thyme (Thymus vulgaris) and rosemary (Rosmarinusofficinalis) essential oils on Brochothrixthermosphacta and on the shelf life of beef packaged in high-oxygen modified atmosphere, Food Microbiology., 32: 212- 216.

4. Al-Snafi, A. E. (2013): Pharmacological effects of Allium species grown in Iraq. An overview. International Journal of Pharmaceutical and health care Research, 1(4), 132-147.

5. Ankri, S., Mirelman, D. (1999): Antimicrobial properties of allicin from garlic. Microbes and Infection, 1: 125- 129.

6. Bakhtiary, F. Sayevand, H. R.,Khaneghah A. M. Haslberger, A. G. and Hosseini, H. (2018): Antibacterial efficacy of essential oils and sodium nitrite in vacuum processed beef fillet. Applied Food Biotechnology, 5(1): 110 .

7. Barbosa, L.N., Rall, V.L., Fernades, A., Ushimaru, P., Da Silva I. and Fernandes, A. (2009): Essential oils against foodborne pathogens and spoilage bacteria in minced meat. Foodborne Pathogens and Disease, 6:725 - 728.

8. Bowles, B.L., Juneja, V.K. (1998): Inhibition of food-borne bacterial pathogens by naturally occurring food additives. Journal of Food Safety, 18: 101-112. 
9. Burt, S. (2004): Essential oils: their antibacterial properties and potential applications in foods-a review. International Journal of Food Microbiology, 94, 223-253.

10. Davidson, P.M., (1997): Chemical preservatives and natural antimicrobial compounds. In: Doyle, M.P., Beuchat, L.R., Montville, T.J. (Eds.), Food Microbiology. Fundamentals and Frontiers.ASM Publications, Washington, DC, pp.

11. Donsí, F., Annunziata, M., Sessa, M. and Ferrari, G. (2011) Nanoencapsulation of essential oils to enhance their antimicrobial activity in foods. Food Science and Technology, 44, 1908-1914.

12. Eid, S.A.S. and Erfan, A.M. (2013):Characterization of $E$ .coli associated with high mortality of poultry flocks . Assiut Vet .Med. J. 59(139): 51-61, Egypt.

13. Es, I., Khaneghah, A. M and Akbariirad, H. (2017): Global regulation of essential oils. Essential oils in food processing: chemistry, safety and applications. Pp. 327-338.

14. Feldman, D., Hoffman, R., Simpson, J. (2003): The solution for data analysis and presentation graphics. $2^{\text {nd }} \mathrm{Ed}$. Abacus Landcripts, Inc., Barkeley, CA, USA.

15. Focke, M., Feld, A., and Lichtenthaler, H. K. (1990): Allicin, a naturally occurring antibiotic from garlic, specifically inhibits acetyl-CoA synthetase. FEBS letters, 261(1): 106108.

16. "FDA" Food and Drug Administration (2001): U.S. Food and Drug Administration: Bacteriological Analytical Manual Online.

17. Gammariello, D., Di Giulio, S., Conte, A. and Del Nobile, M. A. (2008): Effects of natural compounds on microbial safety and sensory quality of Fior di Latte cheese, a typical Italian cheese. J. Dairy Sci., 91 (11): 4138-4146.

18. Giatrakou, V., Ntzimani, A., Savvaidis, I.N., (2010): Combined chitosan-thyme treatments with modified atmosphere packaging on ready-to-cook poultry product. Journal of Food Protection, 73: 663-669.

19. Haq, M., Dutta, P.L., Sultana, N., Rahman, A. (2013): Production and quality assessment of fish burger from the grass carp, Ctenopharyngodonidella (Cuvier and Valenciennes, 1844). Journal of Fisheries, 1: 42-47.

20. Hemin, N. M. (2013): Study of some chemical, physical, sensory and bacteriology characteristics of canned chicken meat imported to Sulaymaniyah markets, Iraq. Int, Nuti. Metabolism., 5: 128-133.

21. Hyldgaard, M., Mygind, T. and Meyer, R. L. (2012): Essential oils in food preservation: mode of action, synergies, and interactions with food matrix components. Frontiers in Microbiology, 3(12): 1-24.

22. "ISO" International Organization for Standardization (1999):Microbiology of food and animal feeding stuffs. Preparation of test samples, initial suspension and decimal dilutions for microbiological examination. Part 1:General rules for the preparation of the initial suspension and decimal dilutions. Reference number ISO 6887-1:1999(E). $1^{\text {st }}$ edition, Cachan, France.

23. Kantachote, D. and Charernjiratrakul, W. (2008): Selection of lactic acid bacteria from fermented plant beverages to use as inoculants for improving the quality of the finished product. Pakistan J. Biol. Sci., 11(22): 2545-52

24. Kaper, J. B., Nataro, J. P., Harry, L.T. (2004): Pathogenic Escherichia coli. Nat. Rev. Microbiol., 2:123-140.

25. Leuschner, R. G. K. and Ielsch, V. (2003): Antimicrobial effects of garlic, clove and red hot chilli on Listeria monocytogenesin broth model systems and soft cheese. Int. J. of Food Sci. and Nut., 54: 127-133.

26. Lombardi-Boccia, G.,Lanzi, S. and Aguzzi, A. (2005) Aspects of meat quality: Trace elements and $\mathrm{B}$ vitamins in raw and cooked meats. Journal of Food Composition and Analysis, 18(1): 39-46.

27. Lorenzo, J. M., Batlle, R. and Gómez, M. (2014): Extension of the shelf-life of foal meat with two antioxidant active packaging systems. LWT- Food Science and Technology, 59: 181-188

28. Morsy, M. K., Khalaf, H.H., Sharoba, A.M., EL-Tanahi, H. H. and Cutter, C.N. (2014): Incorporation of essential oils and nanoparticles in pullulan films to control foodborne pathogens on meat and poultry products. Journal of Food Sci., 79: 675-684.

29. Nevas, M., Korhonen, A.-R., LINDSTRÖM, M., Turkki, P., \& Korkeala, H. (2004): Antibacterial efficiency of Finnish spice essential oils against pathogenic and spoilage bacteria. Journal of food protection,67(1): 199-202.

30. Pranoto, Y.,Salokhe, V. M. and Rakshit, S. K. (2005): Physical and antibacterial properties of alginate based edible film incorporated with garlic oil. Food Research International, 38 (3): 267- 272.

31. Saif-Marwa, Z.M.A. (2015): Bacterial Status of Fresh Marketed chicken cuts. M.V.Sc. Thesis, Meat Hygiene, Fac. Vet. Med., Benha Univ.

32. Salem-Amany, M., Amine-Reham, A. and Gehan-Afifi, S.A (2010): Studies on Antimicrobial and antioxidant efficiency of some essential oils in minced beef. J. Amer. Sci., 6: 691202.

33. Saljoughian, S., Roohinejad, S., Bekhit, A. E. D. A., Greiner, R., Omidizadeh, A.,Nikmaram, N. and Mousavi Khaneghah, A. (2017): The effects of food essential oils on cardiovascular diseases: A review. Critical Reviews in Food Science and Nutrition: 1-18.

34. Sasse, A., Colindres, P., Brewer, M.S. (2009): Effect of natural and synthetic antioxidants on oxidative stability of cooked, frozen pork patties. J. Food Sci., 74: 30-35

35. Shaltout, F.A., Thabet, M.G. and Koura, H.A. (2017): Impact of Some Essential Oils on the Quality Aspect and Shelf Life of Meat. J. Nutr. Food. Sci., 6: 2155-9600.

36. Shen, Z. and Kamdem, D. P. (2015): Development and characterization of biodegradable chitosan films containing two essential oils. International Journal of Biological Macromolecules, 74: 289-296.

37. Skandamis, P.N. and Nychas, G.J.E. (2001): Effect of oregano essential oil on microbiological and physicochemical attributes of minced meat stored in air and modified atmospheres. Journal of Applied Microbiology, 91: 10111022.

38. Solomakos, N., Govaris, A., Koidis, P., Botsoglou, N., (2008): The antimicrobial effect of thyme essential oil, nisin and their combination against Listeria monocytogenes in minced beef during refrigerated storage. Food Microbiology 25: $120-127$.

39. Song Weic Go; Li Baoju and Lui Kai Qi (2004): Advances in research on chemical components in garlic (Allium sativum) and mechanism of their inhibitory reaction with pathogens in plants. Acta Harticulturae Sinica. Chinese Society for Harticultural Science, Beijing, China, 31 (2): 263 - 268

40. Vinceković, M., Viskić, M., Jurić, S., Giacometti, J., Bursać Kovačević, D., Putnik, P. and RežekJambrak, A. (2017): Innovative technologies for encapsulation of Mediterranean plants extracts. Trends in Food Science and Technology, 69: $1-12$.

41. Yadav, A. S. and Singh, R. P. (2004): Natural preservatives in poultry meat products. Natural Product Radiance, 3(4): 300-303. 